\title{
PENURUNAN KEJADIAN LUKA TEKAN GRADE I (NON BLANCHABLE ERYTHEMA) PADA KLIEN STROKE MELALUI POSISI MIRING 30 DERAJAT
}

\author{
Dame Elysabeth Tuty Arna Uly Tarihoran ${ }^{1,2 *}$, Ratna Sitorus ${ }^{3}$, Lestari Sukmarini
}

1. Fakultas Ilmu Keperawatan dan Kesehatan Universitas Pelita Harapan, Tangerang 15811 , Indonesia

2. Program Studi Magister Fakultas Ilmu Keperawatan Universitas Indonesia, Depok 16424, Indonesia

3. Fakultas Ilmu Keperawatan Universitas Indonesia, Depok 16424, Indonesia

*Email: elysabeth_tarihoran@uph.edu,lysa_tarihoran@yahoo.com

\begin{abstract}
Abstrak
Morbiditas dan mortalitas akibat dari luka tekan semakin hari semakin meningkat. Kurangnya aplikasi strategi pencegahan luka tekan berdasarkan rekomendasi terkini. Penelitian ini bertujuan mengidentifikasi pengaruh pengaturan posisi miring 30 derajat mencegah kejadian luka tekan grade I (Non Blanchable Erythema) pada klien stroke dengan imobilisasi. Metode yang digunakan quasi experiment purposive sampling, dengan 33 responden (16 kontrol dan 17 intervensi) kelompok intervensi dan kontrol mendapatkan perawatan sesuai institusi. Kelompok intervensi diberikan aplikasi posisi miring 30 derajat dengan menggunakan penyanggah bantal segitiga. Kejadian luka tekan dievaluasi setelah 3x 24 jam. Hasil penelitian menyatakan perbandingan kejadian luka tekan sangat signifikan ( $p=0,039, \alpha=0,05), R=9,600$, kelompok kontrol berpeluang terjadi luka tekan hampir 10 kali dibanding kelompok intervensi. Pengaturan posisi miring 30 derajat sebaiknya dijadikan sebagai strategi pencegahan luka tekan.
\end{abstract}

Kata kunci: luka tekan, miring 30 derajat, pencegahan, pengaturan posisi, stroke

Abstract

Morbidity and mortality from pressure ulcer are increasing in number. The application of injury prevention strategies based on the recommendations. The aim of this research to identify the effect of 30 degree lateral positioning on the incidence of grade I (Non Blanchable Erythema) pressure ulcer. The method used quasi-experimental with control group study, purposive sampling technique involving 33 patients, divided into 2 groups, (control $n=16$, intervention $n=17$ ). Both groups received the standard of care in the hospital. The intervention group was given 30 degree lateral position by using a triangular pillow. The incidence of grade I pressure ulcer were evaluated within 3x24 hours. The result show that the incidence of pressure ulcer was statistically significant between the group $(p=0,03, \alpha=0,05)$ OR=9.600, where the control group have an almost 10 times the risk to development of grade I pressure ulcer. 30 degree lateral position should be used as a pressure ulcer prevention strategies.

Keywords: pressure ulcer, 30 degree lateral position, prevention, turning position, stroke

\section{Pendahuluan}

Luka tekan adalah cedera yang terlokalisasi pada kulit dan atau jaringan dibawahnya biasanya diatas tonjolan tulang, sebagai akibat adanya tekanan, atau kombinasi dari tekanan dan gesekan (NPUAP-EPUAP, 2009). Luka tekan menimbulkan ancaman dalam pelayanan kesehatan khususnya bagi klien dengan keterbatasan mobilitas, penyakit kronis dan klien-klien lanjut usia. Hal ini menjadi masalah serius karena populasi klien yang berpotensi luka tekan jumlahnya semakin meningkat (Bryant, 2000), di rumah sakit, komunitas, segala tingkat usia, sosial, dan ras (Culley, 2000).
Di Asia, negara Korea, kejadian luka tekan meningkat dari 10\%-45\% (Kim, et al., 2009). Di Indonesia, survei angka kejadian dekubitus di Rumah Sakit Sardjito Yogyakarta pada Oktober 2001, dilaporkan bahwa dari 40 orang klien yang tirah baring, 40\% menderita luka dekubitus (Purwaningsih, 2000 dalam Setiyawan, 2008). Tahun berikutnya Setyajati (2001) melakukan survei angka kejadian luka tekan di Rumah sakit Dr. Moewardi Surakarta, didapatkan 38.18\% klien mengalami luka tekan (Setiyawan, 2008). Indikator standar mutu pelayanan rumah sakit oleh WHO, diadopsi oleh Depkes RI 2001 ditetapkan bahwa sasaran target mutu dekubitus 0\% (Lumenta, 2008). 
Melihat angka kejadian luka tekan yang tinggi di Indonesia, sangatlah wajar, bila masalah luka tekan perlu penanganan khusus.

Insiden luka tekan di rumah sakit lebih tinggi dibandingkan di komunitas seperti yang diungkapkan Hobbs (2004) pada perawatan jangka panjang seperti nursing home berkisar 2,4\% - 23\%, sedangkan di rumah sakit 2,7\% - 29,5\%. Hal diatas cukup ironis, mengingat rumah sakit sebagai tatanan pelayanan rujukan dalam masalah kesehatan. Clark menyatakan bahwa teknologi yang semakin canggih, namun insiden luka tekan tidak pernah turun (Moore, 2004). Semakin menegaskan kembali bahwa tehnologi tidak dapat sepenuhnya menggantikan peran pemberi pelayanan perawatan.

Penelitian tentang bagaimana pengaturan posisi yang paling tepat masih sangat sedikit, terbukti baru 17 literatur yang ditemukan dari 1965 - 2006 (Vanderwee, 2006). Aplikasi pengaturan posisi di tatanan pelayanan kesehatan banyak dilakukan semata-mata berdasarkan rutinitas dan kebiasaan saja. Ini diungkapkan oleh Clark (1998) bahwa perubahan posisi setiap dua jam sekali pada klien seringkali lebih karena mengikuti kebiasaan atau ritual dibandingkan nilai dan makna hasil penelitian yang sebenarnya (Moore, 2004).

Suriadi (2002) membuktikan bahwa imobilisasi adalah faktor resiko yang paling signifikan menyebabkan luka tekan dalam penelitiannya di salah satu rumah sakit di Pontianak (Sari, 2007). Evidence Based Practice mengenai pencegahan luka tekan (Adelaide, 1997) ditemukan empat rekomendasi pengkajian kulit, pembebasan tekanan, penggunaan alat bantu, dan perbaikan kualitas. National Pressure Ulcers Advisory Panel (NPUAP-EPUAP) 2009 menetapkan enam, yaitu pengkajian resiko, pengkajian kulit, nutrisi, pengaturan posisi, penggunaan alat penyanggah, dan populasi khusus. Pada kenyataannya, aplikasinya sangat minim di tatanan pelayanan.

Florence Nightingale (1859) menuliskan "If he has bedshore, it's generally not the fault of the disease, but of the nursing" (Nightingale, 1859 dalam Ayello
\& Lyder, 2008). Perawat sejatinya mempunyai peran yang paling utama sebagai garis pertahanan terdepan yang mencegah dan menjaga klien dari berkembangnya luka tekan (Ayello \& Lyder, 2008).

Pemberian posisi miring 30 derajat bertujuan untuk membebaskan tekanan sebelum terjadi iskemia jaringan dan luka tekan pun tidak terjadi. Tom Defloor meneliti sepuluh posisi yang berbeda-beda, didapatkan bahwa tekanan yang paling minimal dicapai oleh tubuh yakni saat diposisikan miring 30 derajat (Defloor, 2000).

Seiler tahun 2005 (Vanderwee, et al., 2006) menyatakan bahwa luka tekan pada trokanter dan sakral dapat dieliminasi dengan memiringkan klien hingga 30 derajat secara teratur dan menyangganya dengan matras. Maklebust dalam "rule of 30", posisi kepala tempat tidur ditinggikan 30 derajat, posisi badan klien dimiringkan sebesar 30 derajat dapat disanggah dengan bantal busa terbukti klien terbebas dari penekanan pada area trokanter dan sakral (NPUAP, 1996).

Rata-rata angka kejadian luka tekan yang ditemukan di sebuah rumah sakit di Tangerang yakni sebanyak 0,31\% (laporan angka kejadian luka tekan Siloam Hospitals Lippo Village, 2009) dan rumah sakit di Jakarta 0,43\% (laporan angka kejadian luka tekan Siloam Hospitals Kebun Jeruk, 2009). Angka kejadian luka tekan ini masih belum sesuai dengan standar mutu pelayanan kesehatan yang ditetapkan WHO dan Depkes 2001 yakni 0\% (Lumenta, 2008).

\section{Metode}

Penelitian ini menggunakan desain quasi experimental dengan post-test only with control group. Kelompok intervensi dan kontrol mendapatkan intervensi pencegahan luka tekan sesuai standar pelayanan rumah sakit. Ada yang berbeda pada kedua kelompok tersebut yakni pada saat miring kiri/ kanan, seluruh responden pada kelompok intervensi menggunakan bantal segitiga yang telah didisain oleh peneliti untuk menjaga konsistensi perlakuan pada setiap klien. 
Sebagai upaya melindungi hak azasi dan aspek etik mulai dari self determination, privacy, anonymity, informed consent dan protection from discomfort klien diberikan informed consent. Setelah itu pengkajian data karakteristik responden berupa nama, diagnosa, jenis kelamin, usia, nilai albumin, indeks massa tubuh, riwayat merokok, skor skala braden.

Sampel penelitian ini adalah klien stroke (setelah fase akut), mengalami imobilisasi, skor Braden $<17$, menjalani perawatan inap minimal tiga hari. Penelitian dilakukan di rumah sakit yakni SHLV (Intervention group) dan SHKJ (Control group). Kejadian luka tekan dievaluasi setiap perubahan posisi hingga maksimal setelah $3 \times 24$ jam intervensi menggunakan klasifikasi grade luka tekan EPUAP-NPUAP 2009.

Pada penelitian ini dilakukan uji homogenitas terhadap usia, jenis kelamin, jenis stroke, skala Braden, riwayat merokok, kadar albumin, dan indeks massa tubuh pada kelompok kontrol dan intervensi. Untuk mengetahui apakah pengaturan posisi miring 30 derajat berpengaruh terhadap kejadian luka tekan menggunakan Chi Square. Tingkat kemaknaan ditetapkan sebesar 95\%.

\section{Hasil}

Tabel 1. Karakteristik Usia Responden Kelompok Intervensi dan Kelompok Kontrol

\begin{tabular}{lcccccc}
\hline $\begin{array}{c}\text { Jenis } \\
\text { Kelompok }\end{array}$ & n & Mean & Med & SD & $\begin{array}{c}\text { Min- } \\
\text { Maks }\end{array}$ & 95\% CI \\
\hline Intervensi & 17 & 65,06 & 65,5 & 9,91 & $46-78$ & $59,78-70,35$ \\
Kontrol & 16 & 65,88 & 67 & 12,7 & $45-85$ & $59,07-72,68$ \\
\hline
\end{tabular}

Data yang diperoleh selama satu bulan, total responden 33 klien antara lain, 17 (intervensi) dan 16 (kontrol) (tabel 1). Distribusi responden berdasarkan usia rata-rata yakni 65 tahun, stroke hemoragik dan stroke iskemik masing-masing 50\%, $21(63 \%)$ laki-laki dan wanita $12(37 \%)$, skor Braden $>9$ yakni 15 (46\%) klien (tabel2).

Distribusi frekuensi berdasarkan variabel confounding (tabel 3), terdapat $19(58 \%)$ responden berusia $<71$ tahun dan yang berusia $\geq 71$ tahun sebanyak 14 (42\%) responden. Responden dengan riwayat merokok berjumlah 21 (64\%) responden. Kadar albumin responden hampir seimbang dimana 18 (54.5\%) responden memiliki kadar albumin $>3 \mathrm{gr} / \mathrm{dl}$. Distribusi berdasarkan indeks massa tubuh, sebanyak 22 $(66.7 \%)$ responden nilai indeks massa tubuh $>18 \mathrm{~kg} /$ $\mathrm{m}^{2} 33.3 \%$ (tabel 4).

Hasil analisis hubungan antara perlakuan posisi miring 30 derajat dengan kejadian luka tekan (tabel 5), ditemukan bahwa terdapat $6(37,5 \%)$ responden pada kelompok kontrol mengalami luka tekan. Sedangkan pada kelompok intervensi terdapat satu $(5,9 \%)$ responden terjadi luka tekan $(p=0,039, \alpha=0,05)$.

Tabel 2. Distribusi Responden Berdasarkan Usia, Jenis stroke, Jenis kelamin, dan Skala Braden

\begin{tabular}{lcccccc}
\hline Karakteristik & \multicolumn{2}{c}{ In tervensi } & \multicolumn{2}{c}{ Kontrol } & \multicolumn{2}{c}{ Total } \\
& n & \% & n & \% & N & \% \\
\hline Jenis Stroke & & & & & & \\
Stroke Non & 8 & 47.1 & 8 & 50 & 16 & 48 \\
Hemoragik & & & & & & \\
Hemoragik & 9 & 52.9 & 8 & 50 & 17 & 52 \\
Jenis Kela min & & & & & & \\
Laki-laki & 10 & 58.8 & 11 & 68.8 & 21 & 63 \\
Perempuan & 7 & 41.2 & 5 & 31.3 & 12 & 37 \\
Skala Braden & & & & & & \\
Skala Braden $\leq 9$ & 9 & 52.9 & 9 & 56.3 & 18 & 54 \\
Skala Braden $>9$ & 8 & 47.1 & 7 & 43.8 & 15 & 46 \\
Total & 17 & 100 & 16 & 100 & 33 & 100 \\
\hline
\end{tabular}

Kejadian luka tekan grade I (Non Blanchable Erythema) terjadi pada trokanter kanan, trokanter kiri dan siku kiri, trokanter kiri dan tumit kiri, tumit kiri, trokanter kanan dan siku kanan, serta sakrum kuadran kanan atas. Disimpulkan bahwa ada hubungan yang signifikan antara pengaturan posisi dengan kejadian luka tekan. Responden yang tidak diberi posisi miring 30 derajat berpeluang 9,6 kali terjadi luka tekan dibanding dengan responden dengan perlakuan posisi miring 30 derajat $(\mathrm{OR}=9.600)$.

Analisis hubungan antara confounding variable dengan kejadian luka tekan pada kelompok intervensi (tabel 6) menunjukkan tidak adanya hubungan yang signifikan, namun mengindikasikan adanya resiko. 
Responden yang usianya $\geq 71$ tahun beresiko 0,8 kali terjadi luka tekan, merokok beresiko hampir 0,9 kali terjadi luka tekan, responden dengan IMT $<18$ $\mathrm{kg} / \mathrm{m}^{2}$ beresiko 0,8 kali terjadi luka tekan, dan responden dengan albumin $<3 \mathrm{mg} / \mathrm{dL}$, beresiko 0,8 kali mengalami luka tekan.

\section{Pembahasan}

Hasil penelitian ini sesuai dengan penelitian Tom Defloor dimana dari sepuluh posisi yang berbedabeda, didapatkan bahwa tekanan yang paling minimal tercapai saat klien diposisikan miring 30 derajat (Defloor, 2000). Maklebust dalam "rule of 30" dimana kepala tempat tidur ditinggikan 30 derajat, badan klien dimiringkan 30 derajat disanggah bantal busa terbukti membebaskan klien dari penekanan area trokanter, sakral (NPUAP, 1996). Didukung penelitian Seiler tahun 2000 (Vanderwee, et al., 2006), luka tekan area trokanter dan sakral dapat dieliminir dengan memiringkan klien 30 derajat secara teratur, menyangganya dengan matras.

Tabel 3. Distribusi Variabel Confounding Kelompok Intervensi dan Kontrol

\begin{tabular}{|c|c|c|c|c|c|c|}
\hline \multirow{2}{*}{$\begin{array}{c}\text { Variabel } \\
\text { Confounding }\end{array}$} & \multicolumn{2}{|c|}{$\begin{array}{l}\text { Kelompok } \\
\text { Intervensi }\end{array}$} & \multicolumn{2}{|c|}{$\begin{array}{c}\text { Kelompok } \\
\text { Kontrol }\end{array}$} & \multicolumn{2}{|c|}{ Total } \\
\hline & $\mathbf{n}$ & $\%$ & $\mathbf{n}$ & $\%$ & $\mathbf{N}$ & $\%$ \\
\hline \multicolumn{7}{|l|}{ Usia } \\
\hline$\geq 71$ Tahun & 7 & 41.2 & 7 & 43.8 & 14 & 42 \\
\hline$<71$ Tahun & 10 & 58.8 & 9 & 56.2 & 19 & 58 \\
\hline \multicolumn{7}{|l|}{ Riwayat Merokok } \\
\hline Merokok & 9 & 52,9 & 12 & 75 & 21 & 64 \\
\hline Tidak Merokok & 8 & 47,1 & 4 & 25 & 12 & 36 \\
\hline \multicolumn{7}{|l|}{ Kadar Albumin } \\
\hline$\leq 3 \mathrm{gr} / \mathrm{dl}$ & 8 & 47,1 & 7 & 43,8 & 15 & 45,4 \\
\hline$>3 \mathrm{gr} / \mathrm{dl}$ & 9 & 52,9 & 9 & 56,2 & 18 & 54,5 \\
\hline Total & 17 & 100 & 16 & 100 & 33 & 100 \\
\hline \multicolumn{7}{|c|}{ Indeks Massa Tubuh } \\
\hline$\leq 18 \mathrm{~kg} / \mathrm{m}^{2}$ & 6 & 35,3 & 5 & 31,3 & 11 & 33,3 \\
\hline$>18 \mathrm{~kg} / \mathrm{m}^{2}$ & 11 & 64,7 & 11 & 68,7 & 22 & 66,7 \\
\hline
\end{tabular}

Peneliti melihat bahwa pengaruh pemberian posisi miring ini sangat bermakna dalam mencegah terjadinya luka tekan. Hasil penelitian didapat 6 responden dari kelompok yang tidak diberikan posisi miring 30 derajat mengalami luka tekan, sedangkan 17 responden pada kelompok yang diberi posisi miring 30 derajat hanya 1 yang mengalami luka tekan.

\section{Kesimpulan}

Ada pengaruh yang signifikan antara pengaturan posisi dengan kejadian luka tekan grade I (Non Blanchable Erythema) $(\mathrm{p}=0,039, \alpha=0,05)$ dengan nilai $\mathrm{OR}=9,600$, artinya responden yang tidak diberi perlakuan posisi miring 30 derajat mempunyai peluang 9,6 kali untuk terjadi luka tekan dibanding dengan responden yang diberi perlakuan posisi miring 30 derajat. Secara luas, pengaruh pemberian posisi 30 derajat ini akan berdampak pada penurunan angka kejadian luka tekan.

Tabel 4. Uji Homogenitas Kelompok Intervensi dan Kontrol

\begin{tabular}{|c|c|c|c|c|c|c|c|}
\hline \multirow{2}{*}{$\begin{array}{c}\text { Variabel } \\
\text { Confounding }\end{array}$} & \multicolumn{2}{|c|}{ Intervensi } & \multicolumn{2}{|c|}{ Kontrol } & \multicolumn{2}{|c|}{ Total } & \multirow{2}{*}{$\mathbf{p}$} \\
\hline & $\mathbf{n}$ & $\%$ & $\mathbf{n}$ & $\%$ & $\mathbf{N}$ & $\%$ & \\
\hline \multicolumn{8}{|c|}{ Skor Skala Braden } \\
\hline Skala Braden $\leq 9$ & 9 & 52,9 & 9 & 56,2 & 18 & 54 & 1,000 \\
\hline Skala Braden $>9$ & 8 & 47,1 & 7 & 43,8 & 15 & 46 & \\
\hline \multicolumn{8}{|l|}{ Jenis Stroke } \\
\hline SNH & 8 & 47,1 & 8 & 50 & 16 & 48 & 1,000 \\
\hline $\mathrm{SH}$ & 9 & 52,9 & 8 & 50 & 17 & 52 & \\
\hline \multicolumn{8}{|l|}{ Jenis Kelamin } \\
\hline Laki-Laki & 10 & 58,8 & 11 & 68,8 & 21 & 63 & 0,721 \\
\hline Perempuan & 7 & 41,2 & 5 & 31,2 & 12 & 37 & \\
\hline \multicolumn{8}{|l|}{ Usia } \\
\hline$\geq 71$ Tahun & 7 & 41,2 & 7 & 43,8 & 14 & 42 & 1,000 \\
\hline$<71$ Tahun & 10 & 58,8 & 9 & 56,2 & 19 & 58 & \\
\hline \multicolumn{8}{|c|}{ Riwayat Merokok } \\
\hline Merokok & 9 & 52,9 & 12 & 75 & 21 & 64 & 0,282 \\
\hline Tidak Merokok & 8 & 47,1 & 4 & 25 & 12 & 36 & \\
\hline \multicolumn{8}{|l|}{ Kadar Albumin } \\
\hline$\leq 3 \mathrm{gr} / \mathrm{dl}$ & 8 & 47,1 & 7 & 43,8 & 15 & 45,4 & 1,000 \\
\hline$>3 \mathrm{gr} / \mathrm{dl}$ & 9 & 52,9 & 9 & 56,2 & 18 & 54,5 & \\
\hline \multicolumn{8}{|c|}{ Indeks Massa Tubuh } \\
\hline$\leq 18 \mathrm{~kg} / \mathrm{m}^{2}$ & 6 & 35.3 & 5 & 31.3 & 11 & 33,3 & 1,000 \\
\hline$>18 \mathrm{~kg} / \mathrm{m}^{2}$ & 11 & 64,7 & 11 & 68,7 & 22 & 66,7 & \\
\hline
\end{tabular}

Hasil penelitian ini dapat menjadi masukan dalam memodifikasi Standar Prosedur Operasional (SPO) pencegahan luka tekan di institusi pelayanan kesehatan. Bantal segitiga yang didisain oleh peneliti dapat dijadikan alternatif sebagai penyanggah. 
Penelitian selanjutnya perlu dipertimbangkan menambah jumlah sampel lebih besar lagi guna hasil lebih representatif. Diharapkan hasil penelitian dapat diaplikasikan dalam proses belajar mengajar di praktik klinik. Karena institusi pendidikan merupakan tempat sosialisasi yang paling efektif dalam mensosialisasikan evidenced-based practice (TG, RS, YA).

Tabel 5. Pengaruh Pengaturan Posisi Miring 30 Derajat dengan Kejadian Luka Tekan

\begin{tabular}{|c|c|c|c|c|c|}
\hline \multirow[t]{2}{*}{$\begin{array}{c}\text { Variabel } \\
\text { Independen }\end{array}$} & \multicolumn{2}{|c|}{$\begin{array}{c}\text { Variabel Dependen } \\
\text { Luka Tekan }\end{array}$} & $\begin{array}{l}\text { enden } \\
\text { an } \\
\text { Luka } \\
\text { kan }\end{array}$ & \multirow[t]{2}{*}{$\begin{array}{c}\text { OR } \\
95 \% C I\end{array}$} & \multirow[t]{2}{*}{$\mathbf{p}$} \\
\hline & n $(\%)$ & $\mathbf{n}$ & $(\%)$ & & \\
\hline Kontrol & $6 \quad 37,5$ & 510 & 62,5 & 9,600 & 0,039 \\
\hline Intervensi & 5,9 & 16 & 94,1 & $1,002-91,964$ & \\
\hline
\end{tabular}

\section{Referensi}

Adelaide, S.A. (1997). Best practice: Evidence based practice information sheets for health professionals. Australian Nursing Journal, I (1). Diperoleh dari http://www.joannabriggs.edu.

Ayello, E., \& Lyder, C.H. (2008). Pressure ulcers: A patient safety issue (Chapter 12). Diperoleh dari http://www.ahrq.gov/qual/nurseshdbk/docs.

Bryant, R. (2000). Acute and chronic wound: Nursing management. St. Louis: Mosby.

Colin, D. (1996). Comparison of 90 Úand 30Ú laterally inclined positions in the prevention of pressure ulcer using transcutaneous oxygen and carbondioxide pressure. Advances in wound care, 9 (3), 35-38.

Compas, C. (2010). Pressure ulcer prevention and management. Diperoleh dari www.afmc.org/ documents/quality_improve/pu_pres.ppt.

Defloor, T. (2000). The effect of position and mattress on interface pressure. Applied nursing research, $13(1)$.

Dharmono. (2010). Depresi dan stroke saling berhubungan. Balipost. Diperoleh dari http:// www.balipost.com.
Elliot, R., McKinley, S., \& Fox, V. (2008). Quality improvement program to reduce the prevalence of pressure ulcers in an intensive care unit. American journal of critical care, 17 (4), 328-337.

Fisher, A., Wells, G., \& Harrison, M. (2004). Factors associated with pressure ulcers in adults in wcute care hospitals. Journal of Advanced Wound Care, 18 (5), 242-253.

Hobbs, B. K. (2004). Reducing the incidence of pressure ulcers: Implementation of a turn-team nursing program. Journal of gerontological nursing, 30 (11), 46-51.

Kale, E.D. (2009). Efektifitas skala Braden dalam memprediksi kejadian luka tekan di bangsal bedah-dalam RSU Prof. Dr. W.Z. Yohannes Kupang (Tesis Universitas Indonesia, Depok, Jawa Barat). Diperoleh dari http:// www.digilib.ui.ac.id/opac/themes/libri2/ detail.jsp?id=124739.

Kim, E., Lee, S., Lee, E., \& Eom, M. (2009). Comparison of the predictive validity among pressure ulcer risk assessment scales for surgical ICU patients. Australian journal of advanced nursing, 26 (4).

Laporan angka kejadian luka tekan SHKJ (2009). Wound and Diabetic care department Siloam Hospitals Kebun Jeruk.

Laporan angka kejadian luka tekan SHLV. (2009). Wound and Diabetic care department Siloam Hospitals Lippo Village.

Lumenta, N. (2008). Lokakarya PELKESI: Strategi mempersiapkan dan menjaga mutu akreditasi rumah sakit. Diperoleh dari www.scribd.com/doc/ nico-lumenta-Mutu-Akreditasi-RS.

Moore, Z., \& Price, P. (2004). Nurse's attitude, behaviours and perceived barriers towards pressure ulcer prevention, Journal of clinical nursing, 13, 942-951.

National Pressure Ulcer Advisory Panel (NPUAP). (1996). Quick reference guide. Diperoleh dari www.npuap.org/guidelines.

National Pressure Ulcer Advisory Panel-European Pressure Ulcer Advisory Panel (NPUAP- 
EPUAP). (2009). Quick reference Guide Washington DC. Diperoleh dari www.npuap.org/

Sari, Y. (2007). Luka tekan: Penyebab dan pencegahan. Diperoleh dari www.ppni.com.

Setiyawan. (2008). Hubungan tingkat pengetahuan, sikap dengan perilaku perawat dalam upaya pencegahan dekubitus di rumah sakit Cakra Husada Klaten (Tesis master, Universitas Muhammadiyah Surakarta, Jawa Tengah). Diperoleh dari http://etd.eprints.ums.ac.id/908/1/ j220060012.pdf.
Vanderwee, K., Grypdonck, Bacquer, D., \& Defloor, T. (2006). Effectiveness of turning with unequal time intervals on the incidence of pressure ulcer lesions. Journal of advanced nursing, 57, 5968.

Young. (2004). The $30^{\circ}$ tilt position vs the $90^{\circ}$ lateral and supine positions in reducing the incidence of non blanching erythema in a hospital inpatient population. Journal of tissue viability, 14 (3).

Tabel 6. Hubungan antara Usia, Riwayat Merokok, Kadar Albumin, IMT pada Kelompok Intervensi

\begin{tabular}{|c|c|c|c|c|c|c|c|c|}
\hline \multirow{3}{*}{ Variabel } & \multicolumn{4}{|c|}{$\begin{array}{l}\text { Luka Tekan } \\
\end{array}$} & \multirow{2}{*}{\multicolumn{2}{|c|}{ Total }} & \multirow{3}{*}{$\begin{array}{c}O R \\
95 \% C I\end{array}$} & \multirow{3}{*}{$\mathbf{p}$} \\
\hline & \multicolumn{2}{|c|}{ Luka Tekan } & \multicolumn{2}{|c|}{ Tidak Luka Tekan } & & & & \\
\hline & $\mathbf{n}$ & $(\%)$ & $\mathbf{n}$ & $(\%)$ & $\mathbf{N}$ & $\%$ & & \\
\hline \multicolumn{9}{|l|}{ Usia } \\
\hline$>71 \mathrm{Thn}$ & 1 & 14,3 & 6 & 85,7 & 7 & 100 & 0,857 & \\
\hline$\leq 71 \mathrm{Thn}$ & 0 & 0 & 10 & 100 & 10 & 100 & $(0,633-1,160)$ & 0,412 \\
\hline \multicolumn{9}{|l|}{ Merokok } \\
\hline Merokok & 1 & 11,1 & 8 & 88,9 & 9 & 100 & 0,889 & 1,000 \\
\hline Tdk Merokok & 0 & 0 & 8 & 100 & 8 & 100 & $(0,706-1,120)$ & \\
\hline \multicolumn{9}{|l|}{ Nilai IMT } \\
\hline$<18 \mathrm{~kg} / \mathrm{m}^{2}$ & 1 & 16,7 & 5 & 83,3 & 6 & 100 & 0,833 & $\mathbf{0 , 3 5 3}$ \\
\hline $18 \mathrm{~kg} / \mathrm{m}^{2}$ & 0 & 0 & 11 & 100 & 11 & 100 & $(0,583-1,192)$ & \\
\hline \multicolumn{9}{|l|}{ Kadar Albumin } \\
\hline$<3 \mathrm{~g} / \mathrm{dL}$ & 1 & 12,5 & 7 & 87,5 & 8 & 100 & 0.87 & 0,471 \\
\hline$\geq 3 \mathrm{~g} / \mathrm{dL}>$ & 0 & 0 & 9 & 100 & 9 & 100 & $(0,673-1,137)$ & \\
\hline
\end{tabular}

Kita tidak pernah bisa belajar jadi berani dan sabar kalau di dunia ini hanya ada kebahagiaan - Hellen Keller -

Anda tidak akan pernah menemukan kedamaian dengan cara mengabaikan kehidupan.

- Virginia Wolf - 